\title{
SATU KAJIAN TINJAUAN MOTIVASI KEUSAHAWANAN TERHADAP USAHAWAN INFORMAL DI SABAH
}

\section{AN EXPLORATORY STUDY OF ENTREPRENEURIAL MOTIVATION ON INFORMAL ENTREPRENEURS IN SABAH}

\author{
Sorayah Nasip ${ }^{1}$ \\ Faculty of Business, Accountancy, and Economics, Universiti Malaysia Sabah (UMS), Malaysia. \\ (Email: sorayah@ums.edu.my) \\ Rini Suryati Sulong ${ }^{2}$ \\ Faculty of Business, Accountancy, and Economics, Universiti Malaysia Sabah (UMS), Malaysia. \\ (Email: yati2002@ums.edu.my) \\ Sharifah Milda Amirul ${ }^{3}$ \\ Faculty of Business, Accountancy, and Economics, Universiti Malaysia Sabah (UMS), Malaysia.
} (Email: sma@ums.edu.my)

Received date: 08-04-2019

Revised date: 15-08-2019

Accepted date: 13-09-2019

Published date: 15-09-2019

To cite this document: Nasip, S., Sulong, R. S., \& Amirul, S. M. (2019). Satu Kajian Tinjauan Motivasi Keusahawanan Terhadap Usahawan Informal di Sabah. International Journal of Entrepreneurship and Management Practices, 2 (7), 01-12.

DOI: $10.35631 /$ ijemp. 27001

\begin{abstract}
Abstrak: Usahawan dan aktiviti keusahawanan merupakan sumber utama inovasi dan kekuatan ekonomi untuk banyak negara, baik dalam sektor formal mahupun informal. Walaupun kerajaan telah menyediakan pelbagai insentif yang memudahkan sesiapa mendaftar secara formal dan beroperasi secara formal di sektor formal, banyak usahawan memilih untuk tetap berada di kawasan marginal melakukan aktiviti keusahawanan yang informal tanpa produk/perkhidmatan tertentu, premis sebenar, atau sebuah lesen perdagangan. Oleh itu, penyelidik berminat untuk bertanya; apa yang mendorong seseorang untuk menjalankan aktiviti keusahawanan informal? Adakah ia benar-benar berdasarkan faktor "dorongan keperluan" dan/atau "dorongan peluang" seperti yang dicadangkan oleh kajian lepas? Atau adakah terdapat daya pengaruh lain yang terikat pada keadaan pasaran atau nilai budaya yang unik untuk suatu kawasan? Bagi menjawab persoalan ini satu siri kajian kes telah dijalankan untuk memahami bagaimana motivasi peribadi, ciri-ciri dan keadaan persekitaran mempengaruhi keputusan perniagaan. Dalam kajian ini kami berkongsikan dapatan daripada satu kajian kes seorang usahawan membuat kek daripada rumah yang beroperasi dalam sektor informal. Data diperoleh daripada temubual mendalam dan pemerhatian peserta. Dapatan kami mendedahkan bahawa usahawan lebih dipengaruhi oleh peluang keusahawanan (faktor tarikan) berbanding dengan keperluan (faktor tolakan) untuk menjalankan perniagaan. Kajian ini adalah signifikan bahawa ianya mendedahkan analisis keadaan sebenar daripada perspektif usahawan, berbanding dengan faktor praanggap, di mana menyumbang terhadap pemahaman motivasi keusahawanan.
\end{abstract}


Kata Kunci: Sektor Informal, Motivasi Keusahawanan, Aktiviti Keusahawanan Informal

\begin{abstract}
Entrepreneurs and entrepreneurial which made it easier for anyone to formally register their business and operate in the formal sector, many entrepreneurs have opted to remain in the marginal area of conducting informal entrepreneurial activities without a specified product/service, actual premise, or a trading license. Hence, the researchers are interested to ask questions; what motivates a person to conduct informal entrepreneurial activities? Is it really based on "necessity driven" and/or "opportunity driven" factors as suggested by past studies? Or are there other driving forces tied to market conditions or cultural values that are unique to an area? To answer these questions a series of case studies were conducted to understand how personal motivation, characteristics and the conditions of the environment influence business decisions. In this paper, we share the findings from a single-case study of a homemade cake entrepreneur operating in the informal sector. Data was collected through in-depth interviews and participant-observation. Our findings revealed that, the entrepreneur was more influenced by the available entrepreneurial opportunities (pull factor) rather than the necessity (push factor) to do business. This study is significant as it reveals real-situational analysis from the entrepreneur's perspective, rather than preconceived factors, which contributes to the understanding of entrepreneurial motivation.
\end{abstract}

Keywords: Informal Sector, Entrepreneurial Motivation, Informal Entrepreneurial Activity

\title{
Introduction
}

Entrepreneurs and entrepreneurial activity represent a major source of innovation and economic strength for many countries, in both the formal and informal sector. Growth of small-medium enterprises stimulates job creation, whereas innovation can lead to the creation of better products and services. In most developing countries, such entrepreneurial activities that allow individuals to establish and manage a business for profit can occur in both the formal and informal business sectors.

According to Carland, Hoy, Boulton \& Carland (1984, p.358), an entrepreneur can be generally regarded as an individual who establishes and manages a business for the principal of profit and growth. Shane and Venkataraman (2000, p.218) also referred entrepreneurship to the process by which "opportunities to create future goods and services are discovered, evaluated, and exploited'”. In line with this, Scarborough (2012) states that entrepreneurship is about creating something new in an uncertain environment and for profit. Studies in entrepreneurship suggest that the ability to recognize and exploit opportunities brought about by changes in the market involves a complex process made up of the entrepreneur activity. For instance, Kuratko and Audretsch (2009, p.4) suggest that entrepreneurs serve as agents of change; provide creative, innovative ideas for business enterprises; and help businesses grow and become profitable.

In terms of opportunities, informal entrepreneurship provides huge opportunities for anyone looking to try out their skills in starting and managing a small business. Even though most governments have made it easier for anyone to formally register their business and operate in the formal sector, many entrepreneurs have opted to remain in the marginal area of conducting informal entrepreneurial activities (without a specified product/service or actual premise) through a registered trading license. Informal entrepreneurial activity can be 
described as a stepping stone towards the creation of a structured business in the formal economy. These would include economic activities that produce legal goods and services but may not be operating formally in a structured manner or may violate some (non-criminal) rules and regulations (Castells \& Ports, 1989; Adele et al, 2015) such as non-recorded incomes and even the occasional use of barter trade. Mapp and Moore (2015) highlighted that activities of individuals operating in the informal sector are indeed not illegal and it is their decision not to formalize the business. Alatas and Newhouse (2010), further argued about the informal sector may provide flexible employment for women who want to work close to home. Thus, it can be argued that the allure of informal entrepreneurial activity is mainly due to their small size and ease of entry and exits of the informal sector.

According to Department of Statistics Malaysia (DOSM, 2017), 1.36 million employed persons in the informal sector comprising 9.4 per cent share of the total employment in Malaysia which actively involved in non-agricultural sector. The informal sector also possesses strong potential to help alleviate poverty by providing an avenue for people to generate income; particularly those of the lower income group in most developing and underdeveloped economies (Adhikari, 2011; Hemmer \& Mannel, 1989). The importance of this sector cannot be denied.

Hence, this case study was conducted with the aim of analysing real-world experiences of the entrepreneur, with the general aim to identify factors of personal motivation, characteristics and the conditions of the environment that influence business decisions. Our central research question is to understand what motivates a person to conduct informal entrepreneurial activities. In this paper, we shall present a review of literature on entrepreneurial motivation and the informal sector. This will be followed by the methodology and case study analysis of an informal entrepreneur. It is hoped that the findings of this research can further strengthen the existing theories explaining entrepreneurial motivation.

\section{Literature Review}

\section{Informal Sector}

The entrepreneur is the central actor in the creation of a new venture. As stated earlier, an entrepreneur can be regarded as an individual who founded, manages and assumes the responsibilities of a business for growth and profit (Carland, et al., 1984; Segal, et al., 2005). In this study, an informal entrepreneur is defined as someone who becomes self-employed in the informal sector and/or is involved in informal entrepreneurial activities. Williams (2007) referred to the informal entrepreneur as someone who is actively involved in starting a business or who is the owner/manager of a business who engages in paid work that is legitimate in all respects apart from the fact that it is not declared to the state for tax, social security and/or labour law purposes.

The informal sector is known by many names and has been portrayed as the murky sector, the small industry sector and even depicted as employment of a highly casual and unstable nature (Gurtoo \& Williams, 2009). This sector is made up of various activities that involve some form of cash transactions, that are usually unregistered or non-compliance with government regulations, with the primary objective of generating income (Adhikari, 2011; Williams, 2008; Orhan \& Scott, 2001). Due to the very diverse nature of trade activities that make up the informal sector, most definitions have either focused on the characteristics of the sector or the type of people operating in the sector. In terms of literature, there are various characteristics of the informal sector represented but it can be generally summed up as small 
businesses, without regular employees, low initial capital, informal capital from family and friends, flexible hours, and irregular contacts and informal relationships with suppliers (Williams, 2008; Tipple, 2005). The motivations for entrepreneurs that are active in this sector have been reported as being diverse as well, from being necessity-driven as well as opportunity-driven.

\section{Entrepreneurial Motivation}

This study involved the analysis of the entrepreneur on the individual level. Studies on this level have found that entrepreneurs can be inclined to start a business venture by both psychological and non-psychological factors (Shane 2003; Shane \&Venkataraman 2000); but most studies accept that external or situational components act as more critical motivators for business start-ups (Gilad \& Levine, 1986; Watson et al., 1998). Latham and Pinder (2005) suggested that motivation is a psychological process that results from individuals' dealings with their environment. Research by Park (2005) highlighted that entrepreneurs use their prior work experience as a frame of reference that allows them to respond to and find opportunities in their surrounding environment. The love of work is also closely related to the entrepreneurs' ability to identify and take advantage of opportunities in the environment (Park, 2005). Similarly, Baum and Locke (2004) mentioned that 'passion for work' or love of one's work acts as a strong motivator for entrepreneurs as well as helps guide their actions in facing uncertainties in the environment.

The concept of motivation can be viewed as a reason or trigger toward a person's action; as well as referred to as the intentions of the entrepreneur to start the business (Kirkwood, 2009; Williams, 2007; Kolvereid, 1996). Past studies have found that no single motivating factor can be attributed to venture success; but rather, it is the interaction of both internal and external factors of motivation that influences the actions of the entrepreneurs (Aidis et al, 2006; Baum \& Locke, 2004; Carter et al, 2003). Nevertheless, most studies do accept that motivating factors driving entrepreneurs can be categorized into internal reasons, also referred to as 'pull' factors, and external, also referred to as 'push' factors (Dawson \& Henley, 2012; Kirkwood, 2009; Smallbone \& Welter, 2004; Shane, 2003).

The push-pull approach aims to categorise entrepreneurs according to their business motivation (Amit \& Muller, 1995; Feeser \& Dugan, 1989; Gilad \& Levine, 1986; Shapero \& Sokol, 1982). The push factors refer to external, usually negative, conditions that force individuals to engage in self-employment or entrepreneurship because all other options for work are absent or unsatisfactory (Kirkwood, 2009; Aidis et al., 2007; Maritz, 2004; Orhan \& Schott, 2001).For example, the push factor into self-employment mainly due to unemployment, job loss and lack of work opportunities (Sharafizad \& Coetzer, 2016). In addition, the push factor or necessity entrepreneurship involved in business is more requirement-based and the best option available in the absence of employment opportunities (Reynolds et al., 2005). The external factors related to level of income also represent 'push factors', such as low family income or helping family members through making more money (Kumar, 2007; Islam, 2012) as well as the need to earn a reasonable living (Alstete, 2002). Push factors are also related to necessity-driven entrepreneurship, where people are driven into business in order to find a source of income to sustain their livelihood (Williams, 2008; Tipple, 2005).

The pull factors refer to internal motivation factors, which are also referred to as voluntarybased. These factors refer to opportunities that pulled entrepreneurs into this endeavour, out of their own personal choice, to exploit some business opportunities (Kirkwood, 2009; Aidis 
et al., 2007; Maritz, 2004; Orhan \& Schott, 2001). Moreover, the pull factor of motivation portrays the opportunity entrepreneurs which referring to those who start a business to pursue an opportunity (Reynolds et al., 2005). Nevertheless, pull factors, for instance the desire to be one's own boss, increase wealth, change lifestyle or use one's experience, knowledge, and desire for independence also work autonomy can attract an individual to entrepreneurship (Kautonen, 2008; Burke et al., 2002; Amit \& Muller, 1995; Birley \& Westhead, 1994; Gilad \& Levine, 1986). Alstete (2003) further explained that motivational factors such as achievement, using one's skills, being one's own boss, and enjoying one's own are also referred to as pull factors. For example, a study by Ismail, Shamsudin, and Chowdhury (2012) found that majority of women entrepreneurs in northern part of Kedah, Malaysia, were motivated by pull factors such as the need for independence, challenge, to be recognized by the society and desires to seek their own idea. Thus, it can generally be said that if motivation factors are largely external-opportunity related, then being an entrepreneur is viewed as a positive choice (Dawson \& Henley, 2012).

Although much research has been done to analyse the necessity/opportunity dichotomy of entrepreneurial motivation, most of these have not been based on the study of informal entrepreneurs. Therefore, we believe that there is a need to understand the motives of informal entrepreneurs as they make up a significant chunk of our economy.

\section{Methodology}

This study looks at the motivations of an entrepreneur to conduct informal entrepreneurial activities such as micro-business (products \& services) done from home and/or without a permanent business premise. To achieve this objective, we took a qualitative approach to answer questions such as: what motivates a person to conduct informal entrepreneurial activities? Is it based on "necessity driven" and/or "opportunity driven" factors as suggested by past studies? Or are there other driving forces? To answer these questions a series of case studies were conducted to understand how personal motivation, characteristics and the conditions of the environment influence business decisions.

As being part of a larger research project, our research is based on Grounded Theory which supports the development of a theoretical framework towards understanding motivations of informal entrepreneurs. Grounded theory allows us to collect data systematically, thus analysing qualitative data based on inductive analysis in a structured and replicable manner (Urquhart. et al., 2010; Day et al., 2009). Nevertheless, in collecting data, a case study approach, through observations and in-depth interviews, was used in this particular research. The case study approach is suitable for describing, explaining, illustrating, and exploring one or more phenomenon (Gustafsson, 2017; Creswell, 2014; Yin, 2009). A case study approach can be done through multiple case studies or a single case study based on the context of the researcher. A single case study may be referred to as an intensive study about a person, a group of people or a unit that aimed to generalise over several units (Gustafsson, 2017; Yin, 2009). This study applied the latter.

A single-case study research strategy allowed us to analyse the personality, feelings and reallife issues/factors faced by the entrepreneur engaged in informal business. This case was chosen based on the criteria that the entrepreneur is producing and/or selling legal goods and services (economic activity) but may not be operating formally in a structured manner or may violate some (non-criminal) rules and regulations. Through this case study we were able to identify issues faced by the entrepreneur that can contribute to painting the overall picture of informal entrepreneurship. For this single case study, in-depth interviews were conducted at 
various stages and times with the entrepreneur. We also included participant-observation with the entrepreneur, in order to observe first-hand the methods of production and the business process; as well as understand the issues faced by the informal entrepreneur.

Using an information-oriented selection technique, (where cases are chosen based on specific characteristics that aptly represents informal entrepreneurs) we chose this case study as a representation of informal entrepreneurs of a particular area. The case study had to fulfill characteristics that were preset, as a basis for choosing our cases; these included: not having any formal brand name, nor a specific set of products (always changing), and not having a specific/stable premise of business. This case was also chosen as a representative unit of analysis for that geographical area. Finally, the decision to choose this entrepreneur was heavily based on accessibility to collect data through participation-observation of her business. Other than that, we also collect secondary data from existing empirical findings such as from case studies and published informatory articles mainly in professional and trade journals. As for data analysis, we applied data coding following Strauss and Corbin (1990), where the data coding process starts with open coding and moves back and forth to axial coding.

\section{Case Study: An Informal Entrepreneur}

Mrs. Sarinah Sidup, 52 years old, is married and a mother of two. She has been involved in informal business for as long as she can remember; from helping her mother sews clothes while she was still in school, to baking cakes for her children to sell at the office. With this said Mrs. Sarinah has been actively selling various products and providing services (such as tailoring) informally for almost 15 years. She started delving into selling baked goods through informal sales. Specifically, she has been selling baked goods such as cakes, cookies and traditional Malay kuih (e.g. kek lapis, kuih raya, kek coklat) during the holidays. This was mostly through the request of friends of her children and husband. The orders would be mostly high during the Muslim holiday of Aidilfitri, since the serving of cakes and sweet traditional delicacies was a staple in most Malaysian homes.

Most informal business ventures have a tendency to arise from hobbies and interests. This was the case for Mrs. Sarinah. She personally loves baking, especially kek lapis. Most of her children's friends and husband's friends really liked her cakes and asked if they can order from her. That was how the business started. But Mrs. Sarinah does not only sell one type of cake. She always changes the type of products she sells because of her interest to try new recipes. She began from a hobby of trying out new recipes for her family, then to fulfilling orders for holidays (traditional cakes) and birthday celebrations, to mini-catering for familyand-friends' events (such as cupcakes for weddings). Nevertheless, these products or business was never formalized nor was it consistent. She did not advertise, nor did she have any formal platform to sell her products or services. She never actively seeked jobs or orders. It was always based on requests from friends and family.

Nevertheless, Mrs. Sarinah continued to bake and learn new recipes. It was "by chance" one particular day that her husband took one of her traditional snacks, known in Malay as kuih bahulu, to work and it was well received by his friends. In her words, this also started from her personal interests: "I looked and found recipes of bahulu to try baking these types of cakes... because I liked eating them" (personal interview). Hence, she began selling bahulu when friends and family started ordering it in bulk. Sales are also quite high during the holidays, such as Chinese New Year, and for weddings. Since she is a full-time housewife, she decided that she could do this full time, i.e. not only for the holidays. She shared this idea 
with her daughter and sister, and they had agreed to "ask people in their office, if anyone was interested to order kuih bahulu" from them. Thus, began the business of selling cakes for Mrs. Sarinah.

She started selling kuih bahulu in a more organized manner about 3 years ago. This also started from her personal interests, as she found recipes to try baking these types of cakes because she liked eating them. She began selling bahulu when friends and family started ordering it in bulk, also during the holidays, Chinese New Year or weddings. Mrs. Sarinah now sells bahulu, a traditional snack or mini cakes, as well as layered-cakes (kek lapis) on order basis. Most orders are made using social media. Her daughter, sisters and nieces help promote her cakes on the internet and through social media, on platforms such as Instagram, Facebook and Whatsapp. What is interesting is that sales and promotion is still periodical and are done through her daughter's and sister's account; Mrs. Sarinah does not have a social media account, other than Whatsapp (which is only shared with family and friends).

In the past, she had only one oven and she can make as much as 100 packs bahulu a day. But since moving to the island of Labuan, where there are not so many people selling these types of products, she has bought a second oven. Mrs Sarinah mainly conducts the business by herself; as she has no workers, or no one helping her bakes and packs the products. She is able to do so because she is a full-time housewife; her husband and children all have full-time jobs. Nevertheless, her family does help in promoting her cakes and kuih online; they also help to deliver the products to the customers.

Since her business is determined on orders, and since she is doing the baking herself, there is a limit to the number of cakes and kuih that she can produce at a time. Therefore, her income is not set. She sells cakes (kek lapis) around RM80-RM120, pending on size and RM10 per pack for the mini bahulu. Sometimes she can make as much as RM8, 000 for 3 weeks worth of baking, selling kek lapis and bahulu for Raya Aidilfitri holidays; but her income is solely based on the orders made.

Her business is still considered as informal because she does not sell her products under any specific brand. She had only started using a "common" type of packaging when her family suggested for her to promote her products online. She sells her products through her daughter since her daughter has a trading license, as she had previously needed to get one to sell health $\&$ beauty products part-time. She only stated general name for her cakes such bahulu on the packaging. Moreover, she still using the transparent plastic bag for her bahulu packaging as mostly used by other informal entrepreneurs (as illustrated below).

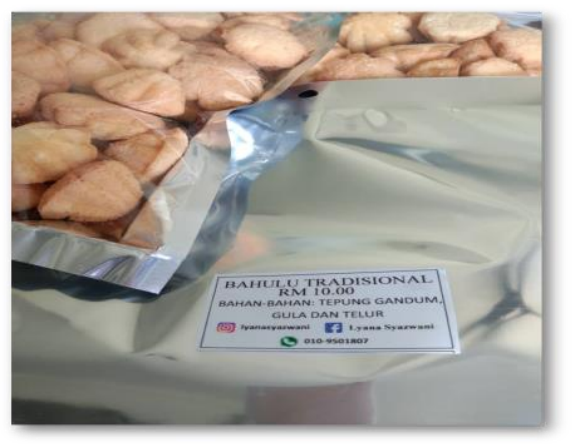

Figure 1: Bahulu Packaging 


\section{Findings}

This case study was conducted with the aim of analysing real-world experiences of the entrepreneur, with the general aim to identify factors of personal motivation, characteristics and the conditions of the environment that influence business decisions. In this study, we applied data coding to derive the concept and motivation for the entrepreneur to conduct business informally. From our research, we found that although there were various factors of motivation that were present, the entrepreneur was motivated mostly by opportunity-based or pull factors to conduct informal entrepreneurial activities.

Based on our interviews and observations, we found that the entrepreneur was pulled into starting and continuing the business because of her interest and love of baking and trying new recipes. This is supported by past researchers that have found that the "love of work" is closely related to the entrepreneurs' ability to identify and take advantage of opportunities in the environment (Park, 2005; Baum \& Locke, 2004). When Mrs. Sarinah was asked plainly why she decided to do this type of informal work, she responded:

"I do this business because I love to do baking and because there is a demand for kuih bahulu, then I just sell it occasionally” (Case Interview, January 2018).

From this, we also can identify that opportunities and the sense to "take a risk" had sprung from her personal interest, as supported by (Ismail, Shamsudin, \& Chowdhury, 2012; Park, 2005).

Aligned with taking advantage of this opportunity to do business, the entrepreneur also did not depend on it solely as a means of income. Instead, it was more of a way to make income from a hobby. For instance, as stated by Mrs. Sarinah when asked if she had to sell cakes as a source of income:

"No...as $i$ don't do the business to merely have income. Baking is my interest and I just sell it when $i$ have special order or a custom order like for wedding gift" (Case Interview, January 2018)

Based on the transcripts above, it shows that Mrs. Sarinah displays a strong level of innovativeness and adaptability to her surroundings. Specifically, in this case, she used all the skills she has in cooking and her contacts (family \& friends) in creating and adapting recipes to suit the needs of her customers. Mrs. Sarinah's way of presenting her products and way of packing and selling to suit her customers' needs is innovative because it involved the creation of new cake designs; of which can be made-to-order.

It is also interesting to note that external factors can play an important role in creating purpose and motivating informal entrepreneurial business. In the case of Mrs. Sarinah, family support can be seen as the motivating factor. As stated:

Example 1:

“...my family members always support me to do this business...even my daughter would promote this kuih in facebook/instagram because I don't know how to use this FB/IG..."

Example 2:

"Kuih bahulu is a traditional cookie, in the market also quite hard to find it...and my family's friends said my bahulu is delicious...they insisted me to keep selling it" 
Thus, it can generally be said that if motivation factors are largely external-opportunity related, then being an entrepreneur is viewed as a positive choice (Dawson \& Henley, 2012).

\section{Conclusions}

We believe this case study has made some contribution toward the understanding of the entrepreneurial motivation towards informal sector's activity based on a single case, which may become a future reference for other entrepreneurs and researchers. Most studies about entrepreneurial motivation in the informal sector triggered by push factors (necessity driven) especially in developing countries. But our study has revealed that pull factor (opportunity driven) as a main motivation to start a business; although not denying the existence of external drivers of motivation. These factors that were found to relate to the entrepreneur's ability to identify opportunities and decide to "try out" or conduct informal business out of their own personal choice are supported by past studies (Kirkwood, 2009; Kautonen et.al., 2008; Aidis et al., 2007; Reynolds et al., 2005; Maritz, 2004; Alstete, 2003; Burke et al., 2002; Orhan \& Schott, 2001; Amit \& Muller, 1995; Birley \& Westhead, 1994).

Findings from this single case study, also supports findings that believe entrepreneurial motivation, particularly from informal entrepreneurs, cannot be categorised as only being necessity driven. Past studies have found that the interaction of both internal and external factors of motivation that influences the actions of the entrepreneurs (Aidis et al, 2007; Baum \& Locke, 2004; Carter et al, 2003) and this can also be true for informal entrepreneurship. However, since it focuses on a single case, therefore the finding is not for generalization. Thus, a further empirical study in a larger context may be performed quantitatively, and several case study approaches may also be adopted to get wider views in understanding entrepreneurial motivation in the informal sector context. Nonetheless, for the benefit of the policy maker, this case study may present some insight about the entrepreneurial activity among informal entrepreneur in informal sectors. Also, the policy might encourage informal entrepreneurs to turn the business into a formal form of business.

\section{Acknowledgement}

UMS Grant SBK0313-2017

\section{References}

Adele, H.A., Oyedokun, J.A., Oyerinde, A.J., \& Ayodele, A.Y. (2015). An examination of factors motivating informal entrepreneurship in Ibadan, South West Nigeria. European Journal of Business and Management, 7(24), 18-30.

Adhikari, D.B. (2011). Income generation in informal sector: a case study of the street vendors of Kathmandu metropolitan city. Economic Journal of Development Issues, 13-14(1-2), 1-14.

Aidis, R., Welter, F., Smallbone, D. \& Isakova, N. (2007). Female entrepreneurship in transition economies: the case of Lithuania and Ukraine. Feminist Economics, 13(2), 157-183.

Alatas, V., \& Newhouse, D. (2010). Indonesia jobs report: Toward better jobs and security for all. Washington, DC: Main Report, World Bank.

Alstete, J. W., (2003). On becoming an entrepreneur: An evolving typology. International Journal of Entrepreneurial Behaviour \& Research, 8(4), 222-234.

Amit, R., \& Muller, E., (1995). Push and pull entrepreneurship. Journal of Small Business Entrepreneurship, 12 (4), 64-80. 
Baum, J. R., \& Locke, E. A. (2004). The relationship of entrepreneurial traits, skill, and motivation to subsequent venture growth. Journal of Applied Psychology, 89(4), 587598.

Birley, S. \& Westhead, P. (1994). A taxonomy of business start-up reasons and their impact on firm growth and size. Journal of Business Venturing, 9(1), 7-31.

Burke, A.E., FitzRoy, F.R. \& Nolan, M.A. (2002). Self-employment wealth and job creation: the roles of gender, non-pecuniary motivation and entrepreneurial ability. Small Business Economics, 19(3), 255-270.

Carland, J.W., Hoy, F., Boulton, W.R., \& Carland, J.A.C. (1984). Differentiating entrepreneurs from small business owners: a conceptualization. Academy of Management Review, 9(2), 354-359.

Carter, N. M., Gartner, W. B., Shaver, K. G., \& Gatewood, E. J. (2003). The career reasons of nascent entrepreneurs. Journal of Business Venturing, 18(1), 13-39.

Castells, M. \& Portes, A. (1989). World Underneath: The Origins, Dynamics and Effects of the Informal Economy, John Hopkins University Press, Baltimore.

Creswell, J.W. (2014). A Concise Introduction to Mixed Method Research. U.S.A.: Sage Publishing.

Dawson, C. \& Henley, A. (2012). Push versus pull entrepreneurship: an ambiguous distinction? International Journal of Entrepreneurial Behavior \& Research, 18(6), 697 719.

Department of Statistics Malaysia 2017 (2018, December 3). Press Release Informal Sector Work Force Survey Report, Malaysia, Retrieved from https://www.dosm.gov.my/v1/index.php?r=column/pdfPrev\&id=TStvalVDc3krRG5h SHByQjczd21FZz09

Feeser, H., \& Dugan, K.W., (1989). Entrepreneurial motivation: a comparison of high and low growth high tech founders. In: Brockhaus Jr., R.H., Churchill, N.C., Katz, J.A., Kirchhoff, B.A., Vesper, K.H., Wetzel Jr., W.E. (Eds.), Frontiers of Entrepreneurship Research. Babson College, Wellesley, Mass., pp. 13-27.

Gilad, B. \& Levine, P. (1986). A behavioral model of entrepreneurial supply. Journal of Small Business Management, 24(4), 45-54.

Gurtoo, A. \& Williams, C.C. (2009). Entrepreneurship and the informal sector: some lessons from India. Entrepreneurship and Innovation, 10(1), 1-7.

Gustafsson, J. (2017). Single Case Studies vs. Multiple Case Studies: A Comparative Study. Academy of Business, Engineering and Science, Halmstad University, Halmstad, Sweden. Retrieved from http://www.divaportal.org/smash/get/diva2:1064378/FULLTEXT01.pdf

Hemmer, H. \& Mannel, C. (1989). On the economic analysis of the urban informal sector. World Development, 17(10), 1543-1552.

Islam S. (2012). Pull and push factors towards small entrepreneurship development in Bangladesh. Journal of Research in International Business Management, 2(3), 65-72.

Ismail, H. C., Shamsudin, F. M., \& Chowdhury, M. S. (2012). An exploratory study of motivational factors on women's entrepreneurship venturing in Malaysia. Business and Economic Research, 2(1), 1-13.

Kautonen, T., Down, S. \& South, L. (2008). Enterprise support for older entrepreneurs: the case of PRIME in the UK, International Journal of Entrepreneurial Behavior \& Research, 14 (2), 85-101.

Kirkwood, J. (2009). Motivational factors in a push-pull theory of entrepreneurship. Gender in Management: An international Journal, 25(5), 346-364.

Kolvereid, L. (1996) Organizational employment versus self-employment: reasons for career choice intentions. Entrepreneurship: Theory and Practice, 20(3), 23-31. 
Kumar, M. (2007). Explaining entrepreneurial success: a conceptual model, Academy of Entrepreneurship Journal, 13(1), 57-77.

Kuratko, D. F., \& Audretsch, D. B. (2009). Strategic entrepreneurship: Exploring different perspectives of an emerging concept. Entrepreneurship Theory \& Practice, 33(1), 117.

Latham, G. P., \& Pinder, C. C. (2005). Work motivation theory and research at the dawn of the twenty-first century. Annual Review of Psychology, 56(1), 485-516.

Mapp, T. \& Moore, W. (2015). The informal economy and economic volatility. Macroeconomics and Finance in Emerging Market Economies, 8(1-2), 185-200.

Maritz, A. (2004). New Zealand necessity entrepreneurs. International Journal of Entrepreneurship and Small Business, 1 (3/4), 255-264.

Orhan, M. \& Scott, D. (2001). Why women enter into entrepreneurship: An explanatory model. Women in Management Review, 16(5), 232-243.

Park, J.S. (2005). Opportunity recognition and product innovation in entrepreneurial hightech start-ups: a new perspective and supporting case study. Technovation, 25,739752.

Reynolds, P., Bosma, N., Autio, E., Hunt, S., De Bono, N., Servais, I., Lopez-Garcia, P. \& Chin, N. (2005). Global entrepreneurship monitor: data collection design and implementation 1998-2003. Small Business Economics, 24(3), 205-231.

Scarborough, N., (2012). Effective Small Business Management: An Entrepreneurial Approach. Massachusetts: Pearson Education Ltd.

Segal, G., Borgia, D., \& Schoenfeld, J. (2005). The motivation to become an entrepreneur. International Journal of Entrepreneurial Behaviour \& Research, 11(1), 42-57

Shapero, A., \& Sokol, L., (1982). Social dimensions of entrepreneurship. In: Kent, C.A., Sexton, D.L., Vesper, K.H. (Eds.), Encyclopaedia of Entrepreneurship. Prentice Hall, Englewood Cliffs, NJ, pp. 70-92.

Shane, S.A. (2003). A General Theory of Entrepreneurship: The Individual-opportunity Nexus, Edward Elgar, Northampton, MA.

Shane, S., \& Venkataraman, S. (2000). The Promise of Entrepreneurship as a Field of Research. Academy of Management Review, 25(1), 217-226.

Sharafizad J, \& Coetzer A, (2016). Women business owners' start-up motivations and network content. Journal of Small Business and Enterprise Development, 23(2), 590610.

Smallbone, D. \& Welter, F. (2004). Entrepreneurship in transition economies: necessity or opportunity driven? Retrieved online (15 August 2018) from https://www.researchgate.net/profile/Friederike_Welter/publication/235966724_Entre preneurship_in_transition_economies_Necessity_or_opportunity_driven/links/00b7d5 22c635f379e4000000/Entrepreneurship-in-transition-economies-Necessity-oropportunity-driven.pdf

Strauss, A. L., \& Corbin, J. M. (1990). Basics of qualitative research: Grounded theory procedures and techniques, Sage, Newbury Park, CA.

Tipple, G. (2005), The place of home-based enterprises in the informal sector: Evidence from Cochabamba, New Delhi, Surabaya and Pretoria. Urban Studies, 42(4), 611-632.

Urquhart, C., Lehmann, H., Myers, M.D. (2010). Putting the Theory Back into Grounded Theory: Guidelines for Grounded Theory Studies in Information Systems. Information Systems Journal, 20(4), 357-381.

Watson, K., Hogarth-Scott, S. \& Wilson, N. (1998). Small business start-ups: success factors and support implications. International Journal of Entrepreneurial Behaviour and Research, 4(3), 217-238. 
Williams, C.C. (2007). The nature of entrepreneurship in the informal sector: evidence from England. Journal of Development Entrepreneurship, 12(2), 239-254.

Williams, C.C. (2008). Beyond necessity-driven versus opportunity-driven entrepreneurship: a study of informal entrepreneurs in England, Russia and Ukraine. International Journal of Entrepreneurship and Innovation, 9(3), 157-165.

Yin, R. K. (2009). Case Study Research: Design and Methods (4th ed.). California: Sage Publications. 